\title{
APPLICATION OF IZOF MODEL FOR ANXIETY AND SELF-EFFICACY IN VOLLEYBALL ATHLETES: A CASE STUDY
}

\author{
APLICAÇÃODO MODELO IZOF PARA ANSIEDADE EAUTOEFICÁCIA EM ATLETAS DE VOLEIBOL: \\ UMESTUDODECASO
}

Original Article

ARTIGo OrIGINAL Artículo Original

\section{APLICACIÓN DEL MODELO IZOF A LA ANSIEDAD Y AUTOEFICACIA EN ATLETAS DE VOLEIBOL: UNESTUDIODECASO}

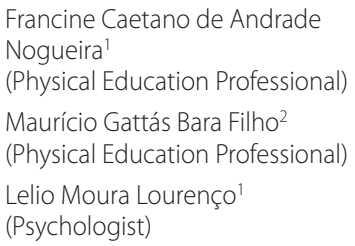

1. Universidade Federal de Juiz de Fora, School of Psychology, Center for Violence and Social Anxiety Studies, Juiz de Fora, MG, Brazil. 2. Universidade Federal de Juiz de Fora, School of Physical Education and Sports, Department of Sports, Juiz de Fora, MG, Brazil.

\section{Correspondence:}

Francine Caetano de Andrade Nogueira.

Rua Barata Ribeiro, 692/703, Copacabana, Rio de Janeiro, RJ. Brazil. 22051-002. francine_andrade_@hotmail.com

\begin{abstract}
Introduction:The relation between psychological variables and their influence on athletic performance have been considered a crucial differential at important time points of the season. Objectives: This study aimed to examine the validity of the IZOF model from a multidimensional perspective of anxiety, and to investigate the possibility of extending the IZOF theory to the self-efficacy construct. Methods: Seven male professional volleyball players participated in the study. The Individual Self-Efficacy Scale for Volleyball and the Competitive State Anxiety Inventory - 2 reduced version were answered by the players before all matches throughout a season. At the end of each match, athletic performance was obtained through the Data Volley program. Results: The results showed the IZOF of self-efficacy and of each subscale of anxiety for the professional team athletes who participated in more than 10 matches during the season. The athletes showed significant variability in scores, ranging from 3 to 5 points for cognitive anxiety, 2 to 7 points for somatic anxiety, 2 to 14 points for self-confidence, and 12 to 54 points for self-efficacy. The findings also indicated that IZOFs are different in an intra- and inter-individual way. We also observed that the number of matches, in percentages across all zones (below, in, and above the IZOF), indicated that Middle Blocker 1 and Opposite 1 presented the best profiles among the 7 players analyzed, as all their variables are in the IZOF zone in the majority of matches, a fact that represents a desired profile for these athletes. Conclusion: Through the analysis of the data, we can attest to the applicability of the IZOF theory for professional volleyball athletes from the multidimensional perspective of anxiety and the possibility of extending the theory to the self-efficacy construct in an attempt to predict the performance of volleyball athletes from this variable. Level of evidence IV; Case series.
\end{abstract}

Keywords: Performance Anxiety; Self Efficacy; Volleyball; Psychology, sport; Athletes.

\section{RESUMO}

Introdução: A relação entre as variáveis psicológicas e a sua influência no desempenho esportivo tem sido considerada um diferencial essencial em períodos importantes da temporada. Objetivos: Examinar a validade do modelo IZOF (Zona Individual de Desempenho Ideal), a partir de uma perspectiva multidimensional da ansiedade e investigar a possibilidade de ampliar a teoria IZOF ao construto da autoeficácia. Métodos: Sete atletas masculinos de voleibol profissional participaram do estudo. A Escala de Autoeficácia Individual para o Voleibol e o Competitive State Anxiety Inventory 2 - versão reduzida foram respondidos pelos jogadores antes de todas as partidas durante uma temporada. No final de cada partida, o desempenho dos atletas foi obtido através do programa Data Volley. Resultados: Os resultados mostraram a IZOF de autoeficácia e de cada subescala de ansiedade para os atletas profissionais que participaram de mais de 10 partidas durante a temporada. Os atletas apresentaram significativa variabilidade nos escores, variando de três a cinco pontos para ansiedade cognitiva, dois a sete pontos para a ansiedade somática, dois a 14 pontos para autoconfiança e 12 a 54 pontos para autoeficácia. Os resultados também indicaram que as IZOFs são diferentes de modo intra e interindividual. Observamos também que o número de partidas, em porcentagens em cada zona (abaixo, dentro e acima da IZOF), indicou que o Central 1 e o Oposto 1 apresentaram os melhores perfis entre os sete jogadores analisados, pois todas as suas variáveis estão na IZOF na maioria das partidas, um fato que representa o perfil desejado para esses atletas. Conclusão: Através da análise dos dados, podemos atestar a aplicabilidade da teoria IZOF para os atletas profissionais de voleibol na perspectiva multidimensional de ansiedade e a possibilidade de ampliar a teoria ao construto da autoeficácia na tentativa de predizer o desempenho de atletas de voleibol por meio dessa variável. Nível de evidência IV; Série de casos.

Descritores: Ansiedade de desempenho; Autoeficácia; Voleibol; Psicologia do esporte; Atletas.

\section{RESUMEN}

Introducción: La relación entre las variables psicológicas y su influencia en el desempeño deportivo se ha considerado un diferencial esencial en períodos importantes de la temporada. Objetivos: Examinar la validez del modelo IZOF (Zona Individual de Desempeño Ideal) a partir de una perspectiva multidimensional de la ansiedade investigar la posibilidad de ampliar la teoría IZOF al constructo de autoeficacia. Métodos: Siete atletas masculinos 
de voleibol profesional participaron en el estudio. La Escala de Autoeficacia Individual para el Voleibol y el Competitive State Anxiety Inventory 2 - versión reducida fueron respondidos por los jugadores antes de todos los partidos disputados durante una temporada. Al final de cada partido, el desempeño de los atletas fue obtenido a través del programa Data Volley. Resultados: Los resultados mostraron la IZOF de autoeficacia y de cada subescala de ansiedad para los atletas profesionales que participaron en más de 10 partidos durante la temporada. Los atletas presentaron significativa variabilidad en las puntuaciones, variando de tres a cinco puntos para la ansiedad cognitiva, dos a siete puntos para la ansiedad somática, dos a 14 puntos para la autoconfianza y 12 a 54 puntos para la autoeficacia. Los resultados también indicaron que las IZOF son diferentes de modo intra e interindividual. También observamos que el número de partidos, en porcentajes en cada zona (debajo, dentro y arriba de la IZOF), indicó que el Central 1 y el Opuesto 1 presentaron los mejores perfiles entre los siete jugadores analizados, ya que todas sus variables están en la IZOF en la mayoría de los partidos, un hecho que representa el perfil deseado para esos atletas. Conclusión: A través del análisis de los datos podemos confirmar la aplicabilidad de la teoría IZOF para atletas profesionales de voleibol en la perspectiva multidimensional de ansiedad y la posibilidad de ampliar la teoría al constructo de autoeficacia en la tentativa de predecir el desempeño de atletas de voleibol por medio de esa variable. Nivel de evidencia IV; Serie de casos.

Descriptores: Ansiedad de desempeño; Autoeficacia; Voleibol; Psicología del deporte; Atletas.

\section{INTRODUCTION}

Psychological variables have been considered a crucial differential in important moments of sports performance. The relation between psychological variables and their influence on athletic performance has been the object of study of Sports Psychology since the end of the 19th century. To date, the progression of knowledge has led to the increased credibility and importance of psychological factors in the sports area. ${ }^{1-4}$ Among the aspects studied extensively in recent decades, we highlight self-efficacy and anxiety.

Self-efficacy can be conceptualized as the individual's own perception of their ability to perform a task successfully. ${ }^{5}$ The self-efficacy belief theory proposed by Bandura, ${ }^{6,7}$ was adapted for sport psychology and forms the theoretical basis adopted by most research. Through an interactive approach, self-efficacy, considered a personal factor, and environmental determinants interact to produce changes in the athlete's future behavior in a reciprocal way. ${ }^{2,8}$

In this context, an important component that interferes in self-efficacy is the level of anxiety. Although the anxiety-performance relationship has been extensively studied in recent decades, there are still no definitive conclusions among researchers. According to Ford, Ildefonso, Jones and Arvinen-Barrow, ${ }^{9}$ some theoretical approaches have been negatively biased, focusing on the anxiety-performance relationship, such as the Catastrophe model proposed by Hardy, ${ }_{1}^{10}$ the drive theory proposed by Hull, ${ }^{11}$ and the inverted-UTheory, proposed by Krane, ${ }^{12}$ based on Yerkes and Dodson's Law, in 1908.

The individual zone of optimal functioning (IZOF) model could correct this bias. According to the IZOF theory proposed by Hanin, 13,14 elite athletes have an ideal anxiety-state zone in which their best performances occur. Outside this zone, above or below it, worse performances occur. Many researchers of the IZOF theory used the State-Trait Anxiety Inventory (STAI), proposed by Spielberger, Gorsuch and Lushene, ${ }^{15}$ which provides an anxiety-state score in a one-dimensional perspective for establishing the optimal performance zone. More recently, some studies have adapted the IZOF theory ${ }^{16,17}$ and used the Competitive State Anxiety Inventory - 2 (CSAI-2), extending the IZOF theory to a multidimensional perspective of anxiety. According to Annesi, ${ }^{17}$ the separation of the anxiety state into three subscales (cognitive, somatic, and self-confidence) is considered advantageous for sports psychologist interventions, as they should apply specific treatment to modify only the variables which the athlete cannot regulate.

Based on the theory of expansion to other emotions, as proposed by Hanin and Syrja, ${ }^{18}$ who extended the IZOF model to the contented and intensity (levels/range) of positive-negative performance emotions, we believe that self-efficacy may also present a model based on IZOF theory, since the self-efficacy-performance relationship has been verified by previous studies. ${ }^{19}$

To clarify the relationship between self-efficacy, anxiety, and sport performance, this study aimed to examine the validity of the IZOF model for these variables in volleyball athletes, from a multidimensional perspective, in an attempt to establish an ideal profile that optimizes performance in an individualized model. In addition, this study also intends to investigate the possibility of extending the IZOF theory to the self-efficacy construct for these athletes. It was hypothesized that volleyball athletes would present individual optimal and non-optimal patterns of cognitive and somatic anxiety, self-confidence, and self-efficacy related to their successful and unsuccessful performances.

\section{METHODS}

\section{Participants}

For the development of this research, a quantitative case study was carried out with seven professional male athletes, members of a high performance volleyball Brazilian titular team; age $26.46 \pm 5.51$, body weight $95.8 \pm 8.2 \mathrm{~kg}$, height $197.0 \pm 7.9 \mathrm{~cm}$, and body fat $14.8 \pm 5.8 \%$. The athletes disputed the Brazilian first national division (Superliga) and the titular team was composed of 2 passer hitters $(\mathrm{PH}), 3$ middle blockers $(\mathrm{MB})$, 1opposite $(\mathrm{O})$, and1 setter $(\mathrm{S})$.

The sample was selected by convenience and the criteria for the inclusion of athletes in this research were the fact that they were in the training process and were members of the titular team, in addition to having their performances computed by the technical commission in at least 10 official matches of the 38 games played throughout the season.

As the sample is composed of elite volleyball players and the data were collection from an entire season, the sample was reduced (7 athletes from a single team), a fact that weakens the generalization of our results. However, the methodology used can be applied to other athletes and teams, thus allowing comparison of the findings. 
All athletes signed an informed consent term attesting to their voluntary participation. The study was approved by the Ethics Committee on Research in Human Beings, protocol number 663 188/2014, in accordance with the Declaration of Helsinki.

\section{Procedures}

On the day of the team presentation for the beginning of the season training, the objectives of the study and instructions on how to complete the instrument were explained to all those involved in the research and all relevant questions clarified. The Individual Self-Efficacy Scale for Volleyball ${ }^{20}$ and the Competitive State Anxiety Inventory - 2 reduced version $(\mathrm{CSAI}-2 \mathrm{R})^{21}$ were completed by the players before all matches played by the team throughout the season.

Athletes were approached individually, about an hour before the start of each match, taking an average of ten minutes to complete the questionnaires. The researchers remained at the site of data collection throughout the procedure. At the end of each game, the performance of the professional athletes was obtained through the Data Volley program, $^{22}$ provided by the technical committee.

\section{Monitoring of anxiety}

We used the CSAI-2R ${ }^{21}$ to measure the level of somatic and cognitive anxiety and self-confidence. This instrument consists of 17 Likert-type questions, in which the subject chooses $1=$ nothing, 2 = something, $3=$ moderate, and $4=$ very, according to the question. A score of 3 subscales (cognitive anxiety - questions 2, 5, 8, 11, and 14; somatic anxiety - questions $1,4,6,9,12,15$, and 17, and self-confidence-questions 3, 7, 10, 13 , and 16 ) is obtained from the sum of responses, with scores ranging from 5 to 20 in the levels of cognitive anxiety and self-confidence and 7 to 28 in the levels of somatic anxiety.

\section{Monitoring of self-efficacy}

The Individual Self-Efficacy Scale for Volleyball ${ }^{20}$ is composed of eight items that question the player about the degree of confidence they have in their ability to perform important skills in the game. Each answer contains a Likert scale of 11 points, ranging from $0=1$ cannot do it at all to $10=$ certainly $I$ can do it. In the process of adaptation and validation for the Portuguese language, the scale presented internal consistency of $a=0.80$ for passer hitters, middle blockers, opposites, and setters, demonstrating applicability for a Brazilian sample.

\section{Monitoring performance}

Performance was monitored in all games throughout the season through the technical indicators (scout) provided by the technical commission that carried out recording during the matches, according to the standards established and applied internationally, through the Data Volley program.22 This software uses fundamental rankings and player identification, with the averages calculated in absolute and percentage values. The evaluative procedure was performed by the statistician who is part of the technical committee, familiar with the instrument and standards.
After entering the individual data of the players regarding the quantity and quality of the actions performed during the match, the Data Volley software provides a game report, with the statistical summary of the fundamentals carried out by each team, divided into players. In this report, a value is given that represents the numerical evolution of the athlete, called the Eva. The Eva is calculated from an overall mean that considers the values of the specific skills performed for each volleyball position and the consequences of their actions for the performance of other athletes and, therefore, for the completion of the point.

\section{Establishment of the IZOF model}

From the athlete performance score (Eva), the mean and individual performance standard deviation were identified, which were used to categorize the best individual performance, i.e., above-average scores, and the worst individual performance, i.e., equal to or below average scores. For the establishment of the IZOF model, the mean scores of cognitive anxiety, somatic anxiety, self-confidence, and self-efficacy of the best matches performed by each athlete were used. From this average, the optimal functioning zone was established for each player by adding and subtracting a half standard deviation from the overall mean (of all games played), for each variable (cognitive anxiety, somatic anxiety, self-confidence, and self-efficacy), as proposed by Hanin \& Syrja (1995). It is noteworthy that the present study sought to expand the IZOF theory for the self-efficacy construct, in addition to anxiety in the multidimensional perspective.

\section{Statistical analysis}

The descriptive analysis is presented as mean \pm standard deviation, after data normality and homoscedasticity verification using the Shapiro-Wilk and Levene's tests, respectively.

The reliability of the questionnaires used was assessed by internal consistency (Cronbach's Alpha). For all analyzes, SPSS software, version 20.0 (IBM Corp., Armonk, NY) was used, adopting the significance level of $5 \%$. The Student's t-test was performed for paired samples to test the differences between the means of the variables when the individual performance was above the mean vs. equal to/below the mean. The same test was also used to compare the performance of the athletes in the IZOF zone and outside the IZOF zone according to the variable investigated.

\section{RESULTS}

The internal consistency analysis showed that the coefficients found (CSAl-2R $r=0.71$; Self-efficacy scale $r=0.90$ ) can be considered high ( $r>$ 0.70), indicating the adequacy of the questionnaires and scales for the athletes surveyed.

Table 1 shows the average of the variables individually, depending on the performance of each athlete. We can observe that $\mathrm{PH} 2$ was the only player who presented significantly lower values of self-efficacy and significantly higher cognitive and somatic anxiety when his performance outcomes were equal to or below the average in relation to his best performance (above the mean).

Table 1. Average variables depending on athlete performance.

\begin{tabular}{|c|c|c|c|c|c|c|c|c|}
\hline \multirow[t]{2}{*}{ Performance/Function } & \multicolumn{4}{|c|}{ Equal to/below the mean } & \multicolumn{4}{|c|}{ Above the mean } \\
\hline & SE & $\operatorname{Cog} A$ & SomA & SC & SE & $\operatorname{Cog} A$ & SomA & SC \\
\hline $\mathrm{S} 1(\mathrm{n}=32)$ & $50.8 \pm 10.9$ & $9.9 \pm 0.8$ & $9.8 \pm 3.1$ & $12.5 \pm 2.2$ & $55.1 \pm 6.9$ & $9.6 \pm 1.2$ & $10.1 \pm 2.8$ & $12.6 \pm 2.2$ \\
\hline MB1 $(n=27)$ & $64.7 \pm 6.0$ & $9.1 \pm 1.4$ & $7.1 \pm 0.3$ & $16.2 \pm 1.8$ & $61.4 \pm 4.0$ & $9.9 \pm 0.3$ & $7.1 \pm 0.5$ & $15.3 \pm 1.1$ \\
\hline MB2 $(n=22)$ & $66.3 \pm 3.6$ & $7.4 \pm 1.8$ & $8.4 \pm 1.2$ & $17.3 \pm 1.4$ & $64.9 \pm 3.7$ & $7.5 \pm 1.9$ & $8.9 \pm 1.6$ & $15.4 \pm 2.7$ \\
\hline MB3 $(n=14)$ & $73.0 \pm 6.4$ & $7.2 \pm 1.8$ & $7.0 \pm 0.7$ & $19.6 \pm 0.9$ & $66.4 \pm 9.2$ & $6.4 \pm 1.1$ & $7.0 \pm 0.1$ & $20.0 \pm 0.1$ \\
\hline $\mathrm{PH1}(\mathrm{n}=32)$ & $64.8 \pm 13.0$ & $6.8 \pm 0.8$ & $7.6 \pm 1.1$ & $16.4 \pm 3.3$ & $67.8 \pm 3.8$ & $6.7 \pm 1.0$ & $7.3 \pm 0.5$ & $18.1 \pm 0.5$ \\
\hline $\mathrm{PH} 2(\mathrm{n}=25)$ & $74.7 \pm 6.1^{*}$ & $6.8 \pm 2.1^{*}$ & $7.9 \pm 0.9^{*}$ & $18.6 \pm 1.4$ & $79.1 \pm 1.7$ & $5.2 \pm 0.4$ & $7.1 \pm 0.3$ & $19.7 \pm 0.9$ \\
\hline $01(n=29)$ & $58.1 \pm 3.8$ & $9.1 \pm 1.6$ & $7.4 \pm 0.6$ & $15.8 \pm 2.1$ & $57.7 \pm 3.3$ & $9.3 \pm 0.7$ & $7.2 \pm 0.6$ & $15.9 \pm 1.3$ \\
\hline
\end{tabular}


When we performed the statistical calculation of IZOF, the optimal zones were established for each athlete in each scale of the CSAI-2R and the self-efficacy scale (Table 2). The athletes demonstrated great variability in scores, ranging from 3 to 5 points for cognitive anxiety, 2 to 7 points for somatic anxiety, 2 to 14 points for self-confidence, and 12 to 54 points for self-efficacy. Through Table 2, we can also observe that the IZOFs are different in an intra and inter-individual way, a fact that supports the individual nature of each zone, characteristic of the theory.

After establishment of each zone, another individual analysis was performed that sought to establish the relationship between the performance of each athlete in each game and their IZOF. Therefore, Table 3 shows the number of games, in percentages, when the athlete demonstrated precompetitive scores below the IZOF, in the IZOF, and above the IZOF.

When observing the percentages in each zone, it can be seen that $\mathrm{MB} 1$ and $\mathrm{O} 1$ presented the best profiles among the 7 players analyzed, as all their variables are in the IZOF zone in the majority of the games, a fact that represents a desired profile for these athletes.

Figures 1 and 2 present these results graphically for the two athletes who presented the best profiles (Middle Blocker 1 and Opposite). Through the graphs, we can visually perceive the performance outcomes inside and outside the IZOF zone. The dashed line indicates the athlete's average performance. Once again, the figures show the great intra and inter-individual variation. Although this ideographic analysis can be performed for all athletes, the present study tried to exemplify it through the two best profiles found among the players.

\section{DISCUSSION}

The present study aimed to establish the IZOF of self-efficacy and of each subscale of anxiety for professional volleyball titular team athletes. Through knowledge of the IZOF for each variable, it was possible to draw an individual profile, in percentages, in order to facilitate the intervention of the professionals involved with the team, since this profile indicates which variables need specific treatment to increase the athlete's ability to regulate their emotions.

The proposal to expand the IZOF theory to the construct of self-efficacy was possible based on the study of Hanin, ${ }^{14}$ who extended this theory beyond anxiety, demonstrating the use of the IZOF for several emotions, such as determination, kindness, and laziness. More recent studies have also sought to broaden the theory to many other positive emotions, such as pleasantness, calmness, confidence, and motivation, and negative emotions such as apprehension, discouragement, insecurity, and fear, and have been able to attest to the effectiveness of the model. ${ }^{23-25}$ In addition, research on self-efficacy in the sports field ${ }^{8,19,26}$ has elucidated the large cause and effect relationship between self-efficacy and sports performance. Moritz et al. ${ }^{27}$ conducted a meta-analysis to investigate the relationship between self-efficacy and sports performance. Based on 45 studies and 102 correlations, the authors found values of $r=0.38$, indicating that self-efficacy beliefs have a positive and moderate relationship with performance.

Based on these relationships, the IZOF theory was applied to self-efficacy and the results of the present study attest to the possibility of using the optimal individual zone for this variable to predict the performance of volleyball athletes. However, it is worth emphasizing that, as mentioned by Bandura, ${ }^{5,7}$ several factors can affect the relationship between self-efficacy and sports performance, such as the type of self-efficacy and performance evaluation, agreement between measurements, nature of the task researched in each sporting modality, and the moment at which the data collection takes place, in other words, the measurements of the two variables must be adequate for each situation that one wishes to research. It is therefore suggested that future studies use other markers of volleyball performance, in addition to the Eva, as a percentage of successful actions, in order to establish other IZOFs for self-efficacy and to confirm the possibility of the theory expansion for this construct.

We believe in the effectiveness of an intervention based on the results of this research, since previous studies, similar to this one, have succeeded in helping athletes achieve their previously calculated optimum performance zones. ${ }^{17,25}$ It seems that the use of IZOF theory proposed by this research is a more individualized and holistic model for assessments and interventions in the area of applied sport psychology.

These analyzes should be performed for all athletes, which will assist sport psychologists to plan more objective interventions with these players. It is believed that these interventions may be positive and increase athlete performance, as demonstrated in a meta-analysis by Jokela and Hanin, ${ }^{28}$ where approximately $60 \%$ of athletes who remained within their IZOF zones performed better than their peers who competed outside their ideal zones.

Table 2. Best performance average, $1 / 2$ standard deviation, and IZOF variation for the self-efficacy and anxiety scales for the titular athletes.

\begin{tabular}{|c|c|c|c|c|c|c|c|c|c|c|c|c|c|c|c|c|}
\hline & \multicolumn{4}{|c|}{ Cognitive Anxiety } & \multicolumn{4}{|c|}{ Somatic Anxiety } & \multicolumn{4}{|c|}{ Self-confidence } & \multicolumn{4}{|c|}{ Self-efficacy } \\
\hline & $M$ & $1 / 2$ SD & Range & IZOF & $M$ & $1 / 2 S D$ & Range & IZOF & $M$ & $1 / 2 S D$ & Range & IZOF & $M$ & $1 / 2 S D$ & Range & IZOF \\
\hline $\mathrm{S} 1$ & 9.8 & 0.5 & $8-13$ & $9.3-10.3$ & 9.6 & 1.3 & $7-14$ & $8.3-10.9$ & 12.5 & 1.4 & $6-20$ & $11.1-13.9$ & 53.4 & 4.5 & $33-72$ & $48.9-57.9$ \\
\hline MB1 & 10.0 & 0.6 & $7-11$ & $9.4-10.6$ & 7.1 & 0.2 & $7-9$ & $6.9-7.4$ & 15.4 & 0.8 & $15-20$ & $14.6-16.2$ & 62.1 & 3.0 & $53-80$ & $59.1-65.1$ \\
\hline MB2 & 7.7 & 0.9 & $5-10$ & $6.8-8.6$ & 8.7 & 0.6 & $7-11$ & $8.1-9.3$ & 16.5 & 1.1 & $10-20$ & $15.4-17.6$ & 65.4 & 2.0 & $59-71$ & $63.4-67.4$ \\
\hline MB3 & 6.2 & 0.7 & $5-11$ & $5.5-6.9$ & 7.0 & 0.1 & $6-8$ & $6.9-7.1$ & 19.6 & 0.4 & $18-20$ & $19.2-20.0$ & 69.2 & 3.1 & $51-80$ & $66.1-72.3$ \\
\hline $\mathrm{PH} 1$ & 6.7 & 0.4 & $5-8$ & $6.3-7.1$ & 7.3 & 0.3 & $7-10$ & $7.0-7.6$ & 18.0 & 1.4 & $8-20$ & $16.6-19.4$ & 68.8 & 4.5 & $22-76$ & $64.3-73.3$ \\
\hline $\mathrm{PH} 2$ & 5.8 & 0.7 & $5-11$ & $5.1-6.5$ & 7.3 & 0.3 & $6-10$ & $7.0-7.6$ & 19.5 & 0.6 & $16-20$ & $18.9-20.1$ & 78.4 & 2.1 & $61-80$ & $76.3-80.5$ \\
\hline 01 & 9.2 & 0.6 & $7-12$ & $8.6-9.8$ & 7.2 & 0.2 & $7-9$ & $7.0-7.4$ & 15.9 & 0.8 & $11-18$ & $15.1-16.7$ & 57.7 & 1.8 & $51-63$ & $55.9-59.5$ \\
\hline
\end{tabular}

M: Mean of the best performances; SD: General Standard Deviation; S: Sitter; MB: Middle Blocker; PH: Passer Hitter; O: Opposite.

Table 3. Percentage of anxiety and self-efficacy levels when the athlete is above, below, or in the IZOF zone.

\begin{tabular}{|c|c|c|c|c|c|c|c|c|c|c|c|c|}
\hline & \multicolumn{4}{|c|}{ Below the IZOF } & \multicolumn{4}{|c|}{ In the IZOF } & \multicolumn{4}{|c|}{ Above the IZOF } \\
\hline & $\operatorname{Cog} A(\%)$ & SomA (\%) & SC (\%) & SE (\%) & $\operatorname{Cog} A(\%)$ & SomA (\%) & SC (\%) & SE (\%) & $\operatorname{Cog} A(\%)$ & SomA (\%) & SC (\%) & SE (\%) \\
\hline $\mathrm{S1}$ & 28.1 & 46.9 & 37.5 & 21.9 & 59.4 & 21.9 & 6.3 & 40.6 & 12.5 & 31.2 & 56.2 & 37.5 \\
\hline MB1 & 22.2 & 7.4 & 22.2 & 18.5 & 70.4 & 92.6 & 77.8 & 44.4 & 7.4 & 0 & 0 & 37.1 \\
\hline MB2 & 31.8 & 54.5 & 31.8 & 31.8 & 36.4 & 13.6 & 36.4 & 31.8 & 31.8 & 31.8 & 31.8 & 36.4 \\
\hline MB3 & 28.6 & 7.1 & 14.3 & 21.5 & 21.4 & 78.6 & 85.7 & 35.7 & 50 & 14.3 & 0 & 42.8 \\
\hline $\mathrm{PH} 1$ & 46.9 & 0 & 37.5 & 21.9 & 28.1 & 71.9 & 21.9 & 71.9 & 25 & 28.1 & 40.6 & 6.2 \\
\hline $\mathrm{PH} 2$ & 57.7 & 3.9 & 23.1 & 15.4 & 23.1 & 61.5 & 76.9 & 84.6 & 19.2 & 34.6 & 0 & 0 \\
\hline 01 & 28.1 & 0 & 15.6 & 21.9 & 40.6 & 81.2 & 50 & 50 & 31.3 & 18.8 & 34.4 & 28.1 \\
\hline
\end{tabular}



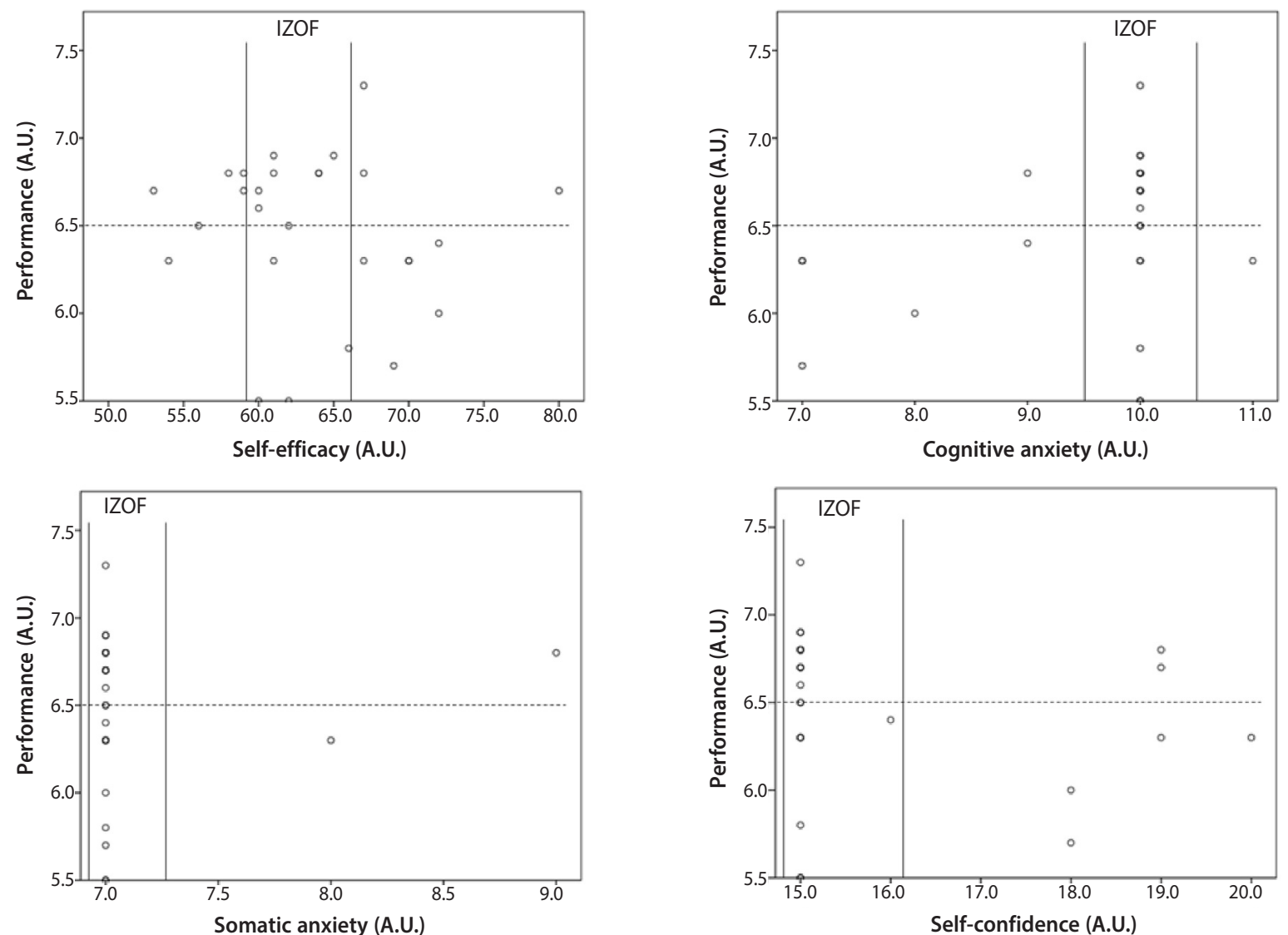

Figure 1. Self-efficacy levels and scales of the CSAI-2R in/outside the zone and the corresponding performance of MB1.
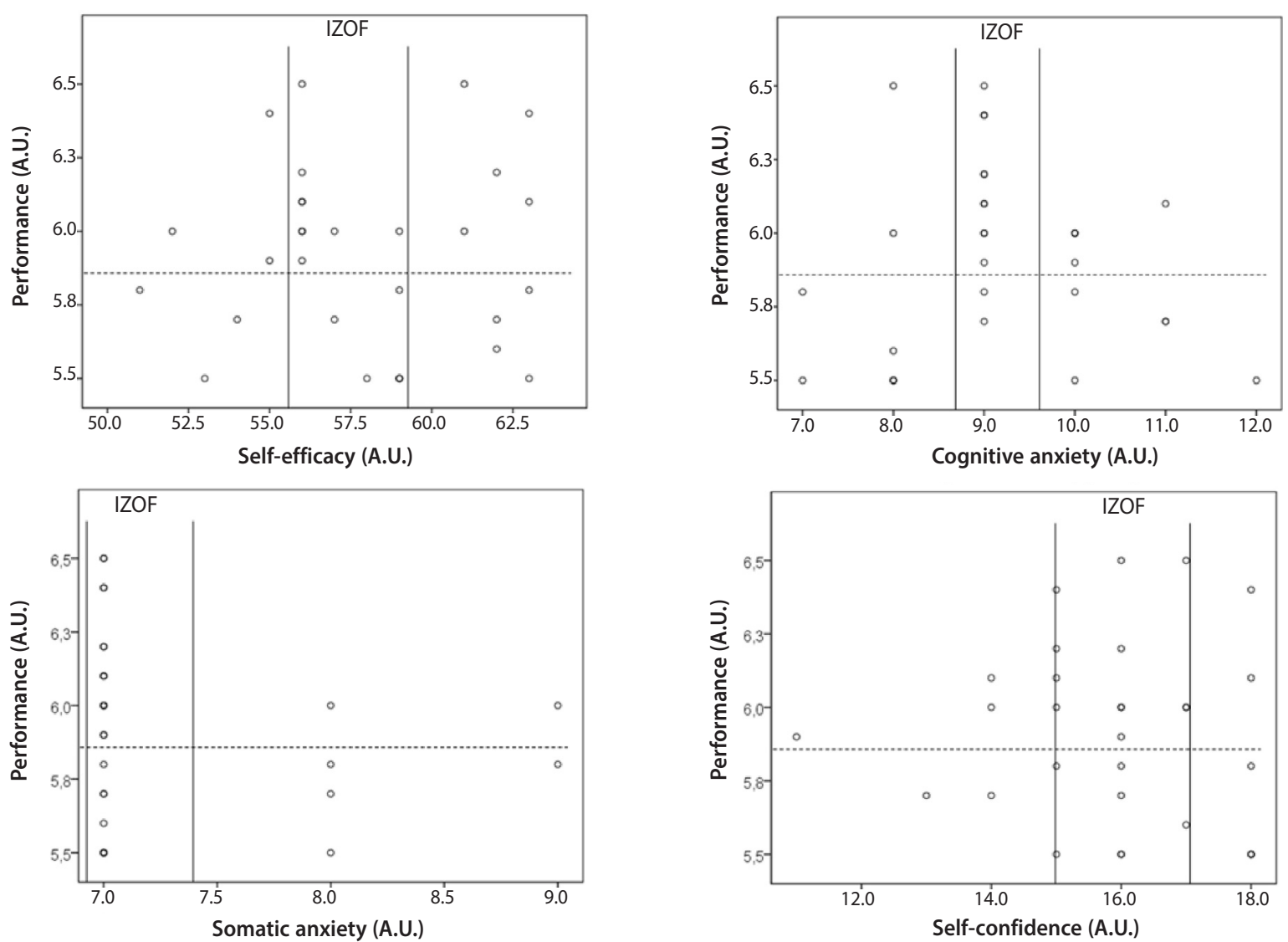

Figure 2. Self-efficacy levels and scales of the CSAI-2R in/outside the zone and the corresponding performance of O1. 
This study has some limitations such as the small sample of athletes from the same team, which characterizes it as a case study. This fact hinders generalization of the results found in a safe way, requiring other similar research for possible comparisons. In addition, athletic performance was only evaluated by the Eva, which is another limiting factor. However, we believe that the application of the methodology used to calculate the IZOF zones and establish the athlete's profiles should be encouraged in other teams and sports modalities because this will facilitate psychological interventions in an attempt to optimize the performance of elite athletes.

\section{CONCLUSIONS}

Through analysis of the data, we can attest to the applicability of the IZOF theory for professional volleyball athletes in the multidimensional perspective of anxiety and also the possibility of extending the theory to the self-efficacy construct in an attempt to predict the performance of volleyball athletes from this variable. These results facilitate interventions by sports psychologists, since the establishment of IZOFs indicates, in an objective way, which variables need specific treatment to increase the athlete's ability to regulate their emotions. However, future studies that use other markers of volleyball performance, in addition to the Eva, such as the percentage of successful actions, are necessary to establish other IZOFs for self-efficacy and to confirm and strengthen the possibility of the theory expansion for this construct.

All authors declare no potential conflict of interest related to this article

AUTHORS' CONTRIBUTIONS: Each author made significant individual contributions to this manuscript. FCAN (0000-0001-7754-3087)*: design of the article, writing, revision, statistical analysis, data analysis and interpretation; MGBF (0000-0003-1219-8379)*: design of the article, revision, data interpretation and final approval of the version of the manuscript. LML $(0000-0003-3664-7335)^{*}$ : design of the article, revision, and final approval of the version of the manuscript *ORCID (Open Researcher and Contributor ID).

\section{REFERENCES}

1. Englert C, Bertrams A. Anxiety, ego depletion, and sports performance. J Sport Exerc Psychol. 2012;34(5):580-99.

2. Weinberg RS, Gould D. Foundations of Sport and Exercise Psychology. 6th ed. Champaign, IL: Human Kinetics; 2015.

3. Fortes LS, Lira HA, Lima RC, Almeida SS, Ferreira ME. Mental training generates positive effect on competitive anxiety of young swimmers? Rev Bras Cineantropom Desempenho Hum. 2016;18(3):353-62.

4. Fortes LS, da Costa BD, Paes PP, do Nascimento Júnior JR, Fiorese L, Ferreira ME. Influence of CompetitiveAnxiety on Heart Rate Variability in Swimmers. J Sports Sci Med. 2017;16(4):498-504.

5. Bandura A. Self-efficacy: the exercise of control. New York: W.H. Freeman; 1997.

6. Bandura A. Self-efficacy: toward a unifying theoryofbehavioral change. Psychol Rev. 1977;84(2):191-215.

7. Bandura A. Social fundations of thought and action: a social cognitive theory. Englewood Clifs: Prentice-Hall; 1986.

8. Sari I, Bayazit B. The relationship between perceived coaching bahaviours, motivation and self-efficacy in wrestlers. J Hum Kinet. 2017;57:239-51

9. Ford JL, Ildefonso K, Jones ML, Arvinen-Barrow M. Sport-related anxiety: current insights. Open Access J Sports Med. 2017;8:205-12.

10. Hardy L. Testing the predictions of the cuspcat astrophe model of anxiety and performance. Sport Psychol. 1996;10:140-56

11. Hull C. Principles of Behavior. New York: Appleton-Century-Crofts; 1943

12. Krane V. Conceptual and methodological considerations in sport anxiety research: from the inverted-U hypothesis to catastrophe theory. Quest.1992;44(1):72-87.

13. Hanin YL. State and trait anxiety research on sports in the USSR. In: Spielberger CD, Diaz-Guerreo R, editors. Cross-cultural anxiety. Washington, DC: Hemisphere; 1986. p.45-64

14. Hanin YL. Emotions and athletic performance: Individual zones of optimal functioning. Eur Yearbook Sport Psychol. 1997;1:29-72

15. Spielberger CD, Gorsuch RL, Lushene RE. Manual for the State-Trait Anxiety Inventory. Palo Alto, CA: Consulting Psychologists Press; 1970.

16. Woodman T, Albinson JG, Hardy L. An investigation of the zones of optimal functioning hypothesis within a multidimensional framework. J Sport Exerc Psychol. 1997;19:131-41

17. Annesi JJ. Applications of the Individual Zones of Optimal Functioning Model for the Multimodal Treatment of Precompetitive Anxiety. Sport Psychol; 1998;12(3):300-16.

18. Hanin Y, Syrjä P. Performance affect in junior ice hockey players: an application of the individual zones of optimal functioning model. Sport Psychol. 1995;9(2):169-87.

19. García Naveira A. Autoeficacia y rendimiento en jugadores de fútbol. Cuad Psicol Deporte; 2018;18(2):68-79.

20. Carmo AP. Adaptação e validação de uma escala de auto eficácia para o voleibol. [Dissertação de Mestrado]. Piracicaba: Universidade Metodista de Piracicaba. Núcleo de Corporeidade, Pedagogia do Movimento e Lazer, Curso de Mestrado em Educação Física; 2006.

21. Fernandes MG, Vasconcelos-Raposo J, Fernandes HM. Propriedades psicométricas do CSAI-2 em atletas brasileiros. Psicol Reflex Crít. 2012;25(4):679-87.

22. Data Volley 2, User Manual, atualizado até a versão 2.0.4. Data Project Sport Software [Internet]. 2007 [acesso em 2015 mar 20]. Disponível em: http://data-volley-2007.software.informer.com/ Download-gr\%C3\%A1tis

23. Cohen AB, Tenenbaum G, English RW. Emotions and golf performance: An IZOF-based applied sport psychology case estudy. Behav Modif. 2006;30(3):259-80.

24. Hagtvet KA, Hanin YL. Consistency of performance-related emotions in elite athletes: Generalizability theory applied to the IZOF model. Psychol Sport Exerc. 2007:8(1):47-72

25. Woodcock C, Cumming J, Duda لL, Sharp LA. Working within an Individual Zone of Optimal Functioning (IZOF) framework: consultant practice and athlete reflections on refining emotion regulation skills. Psychol Sport Exerc. 2012;13(3):291-302

26. Jurko D, Nešić G, Stojanovic T. Does precompetitive anxiety affect perceived competitive efficacy of volleyball players? FU Phys Educ Sport. 2013;11(1):57-64

27. Moritz SE, Feltz DL, Fahrbach KR, Mack DE. The relation of self-efficacy measures to sport performance: A meta-analytic review. Res Q Exerc Sport. 2000;71(3):280-94

28. Jokela M, Hanin YL. Does the individual zones of optimal functioning model discriminate between successful and less successful athletes? A meta-analysis. J Sports Sci.1999;17(11):873-87. 